\title{
Upaya untuk Meningkatan Hasil Belajar Matematika dan Ketrampilan Berpikir Kritis Siswa Melalui Penerapan Kontekstual dengan Model Learning Community
}

\author{
Rani Laksmita ${ }^{*}$ \\ PGSD-FKIP Universitas Kristen Satya Wacana, Indonesia
}

\author{
A R T I C L E I N F O \\ Article history: \\ Received 19 February \\ 2019 \\ Received in revised form \\ 30 March 2019 \\ Accepted 10April 2019 \\ Available online 26 May \\ 2019 \\ Kata Kunci: \\ Matematika, Hasil Belajar, \\ Komunitas Belajar, \\ Berpikir Kritis, Siklus 1, \\ Siklus 2 \\ Keywords: \\ Mathematics, Learning \\ Outcomes, Learning \\ Community, Critical \\ Thinking, Cycle 1, Cycle 2.
}

\begin{abstract}
A B S T R A K
Tujuan dari penelitian ini adalah untuk mengetahui bagaimana metode Contextual Teaching and Learning with Learning Community mampu meningkatkan hasil belajar matematika dan keterampilan berpikir kritis siswa di SDN Salatiga 05 dan mendeskripsikan penerapan metode Learning Community. Jenis penelitian adalah penelitian tindakan kelas kolaborasi. Dan subjek penelitian ini adalah siswa kelas IV di SDN Salatiga 05 yang terdiri dari 20 siswa. Penelitian ini dilakukan pada Maret 2019, yang terdiri dari pra siklus, siklus satu, dan siklus dua.. Instrumen penelitian untuk mengumpulkan data seperti lembar observasi dan tes evaluasi dianalisis secara kuantitatif. Hasil penelitian menunjukkan pembelajaran dapat meningkatkan hasil belajar bagi siswa. Dan itu menyetujui hasil akademik, dari pra-siklus ke siklus satu ada peningkatan $00 \%$. Dan itu juga menunjukkan hasil yang signifikan pada siklus dua yang meningkat $00 \%$.. Kondisi proses pembelajaran sedikit demi sedikit kondusif sampai siswa benar-benar menikmati dan penggemar bergabung dalam kegiatan. Para siswa menunjukkan peningkatan selama siklus satu ke siklus dua dengan melakukan pekerjaan yang baik pada peran mereka. Dengan demikian metode Learning Community diterapkan untuk siswa dan mendapatkan hasil yang baik untuk hasil belajar dan pemikiran kritis siswa.
\end{abstract}

\section{A B S T R A C T}

The purpose of this research is to know how the Contextual Teaching and Learning with Learning Community method is able to increase the mathematics learning outcomes and critical thinking skills of students at SDN Salatiga 05 and describing the implementation of Learning Community method. The research type is collaboration classroom action research. And the subject of this research is the fourth grade students at SDN Salatiga 05 consist of 20 students. This research did on March 2019, that consist of pre-cycle, cycle one, and cycle two.. The research instrument for collect the data such as observation sheets and an evaluation test analyzed quantitatively. Observation sheets have purpose to know how the Learning Community that apply on the class can give the good benefit for the students. Classroom teacher have an opportunity to give the value and comment during the learning process for repairing on the next cycle. In the evaluation test students get some test during the cycle one and cycle two, it have purpose to know how the Learning Community can increase the learning outcomes for the students. And that approve on the result of academic, from precycle to cycle one there is $00 \%$ increased. And also it show the significantly result on the cycle two that was $00 \%$ increased. The condition of the learning process was little by little conducive until the students really enjoy and enthusiasts join in the activities. The students show the improvement during the cycle one to cycle two by did a great job on their role. Thus Learning Community method was implemented for the students and get the good result for learning outcomes and critical thinking of the students. 


\section{Pendahuluan}

Sebuah pembelajaran yang efektif adalah terjadinya hubungan dan kerjasama antara guru dan siswa. Guru menjadi fasilitator dan siswa mendapat kesempatan untuk meningkatkan keaktifannya di dalam kelas. Menurut (Benjamin, 2005) membagi tujuan pendidikan menjadi tiga ranah, yaitu ranah kognitif, afektif, psikomotorik. Dari tiga ranah ini salah satunya yaitu ranah kognitif, yaitu kemampuan siswa untuk melihat dan mendefinisikan sesuatu secara mandiri berdasarkan hasil pemahaman mereka untuk mencapai ketuntasan pada hasil belajar yang diinginkan.

Suatu pencapaian dari materi dan kegiatan belajar mengajar di dalam kelas akan terwujud dalam sebuah hasil belajar. Menurut (Mulyasa, 2008) adalah prestasi belajar siswa secara keseluruhan yang menjadi indikator kompetensi dan derajat perubahan perilaku yang bersangkutan. Kompetensi yang harus dikuasai siswa perlu dinyatakan sedemikian rupa agar dapat dinilai sebagai wujud hasil belajar siswa yang mengacu pada pengalaman langsung. Dapat disimpulkan bahwa hasil belajar adalah proses alami yang bisa dikembangkan baik oleh guru maupun siswa untuk mencapai tingkat pencapaian dari tujuan pembelajaran. Ini semua tidak terlepas dari pedoman pembelajaran untuk mencapai tujuan utama yang sudah dibuat oleh para pendidik yang disebut dengan indikator. Menurut (Benjamin, 2005) membagi tujuan pendidikan menjadi tiga ranah, yaitu ranah kognitif, afektif, psikomotorik. Setiap ranah memiliki tujuan mengembangkan kemampuan siswa dalam banyak hal. Indikator hasil belajar akan berjalan dengan baik apabila semua ranah dapat dijalankan dengan baik pula.

Salah satu upaya yang dapat dilakukan adalah menerapkan sistem dan pendekatan baru untuk memperbaiki kegiatan belajar mengajar maupun hasil belajar siswa. Berikut adalah pendekatan yang harus dilakukan yaitu pendekatan kontekstual atau sering dikenal dengan Contextual Teaching and Learning. Pendekatan kontekstual ini memiliki tujuh model dan salah satunya adalah Learning Community (Muslich, 2011). Pembelajaran yang diperoleh melalui kerjasama dengan orang lain yang dapat dilakukan melalui kelompok belajar. Hasil belajar dapat diperoleh dari hasil sharing antar teman maupun antar kelompok, diharapkan dapat meningkatkan hasil belajar siswa dan mereka belajar tentang kerjasama serta berbagi pengetahuan satu sama lain. Dalam mewujudkan penerapan kontekstual dengan model learning community. Masih sering ditemukan siswa masih sering mengandalkan teman sesama kelompoknya untuk menyelesaikan tugas kelompok yang diberikan guru, siswa cenderung pasif, memilih sibuk dengan di sekitar mereka, kurang antusias, dan keterbatasan dalam menggunakan media pembelajaran. Tetapi dalam penerapan model ini setiap anggota dalam kelompok akan mendapatkan peran masing-masing guna meningkatkan rasa tanggungjawab dan kemampuan mereka dalam memecahkan masalah. Pendekatan kontekstual berfokus pada keterlibatan siswa secara aktif dalam menggabungkan beberapa materi dengan lingkungan sekitar. Penjelasan ini juga didukung oleh pendapat ahli seperti (Nurhadi, 2003) CTL (Contextual Teaching and Learning) adalah konsep belajar yang mendorong guru untuk menghubungkan antara materi yang diajarkan dan situasi dunia nyata siswa. CTL adalah konsep belajar yang membantu guru mengkaitkan antara materi yang diajarkanya dengan situasi dunia nyata siswa dan mendorong siswa membuat hubungan antara pengetahuan yang dimilikinya dengan penerapan dalam kehidupan sehari-hari.

Alasan dipilihnya model ini, karena model Learning Community ini karena pada dasarnya model ini akan membantu siswa melaksanakan kegiatan mandiri dalam kelompok dengan pembagian peran yang adil dan setiap anggota akan memiliki tanggungjawab yang besar untuk hasil kerja kelompok yang maksimal. Melihat kondisi tersebut peneliti memilih penelitian tindakan kelas tentang "Upaya untuk Meningkatkan Hasil Belajar Matematika dan Ketrampilan Berpikir Kritis Siswa melalui Penerapan Metode Kontekstual dengan Model Learning Community Kelas IV SDN Salatiga 05 Tahun Pelajaran 2019/2020."

\section{Metode}

Penelitian ini dilakukan dengan menggunakan penelitian tindakan kelas (PTK). Penelitian tindakan kelas menurut (Mills, 2000) merupakan penelitian tindakan yang bersifat systemic inquiry, yaitu penlitian tindakan kelas (PTK) dilakukan oleh pendidik (guru dan dosen) dan kepala sekolah atau pejabat struktural di lingkungan perguruan tinggi, karena kepala sekolah dan pejabat struktural mempunyai jabatan fungsional pendidik yaitu wajib membelajarkan peserta didik. Metode dan model yang diambil adalah sistem belajar penerapan metode kontekstual menggunakan metode Learning Outcomes.

Penelitian yang digunakan adalah PTK (Penelitian Tindakan Kelas). Penelitian ini dilakukan menurut (Saur, 2014) yang dilakukan dalam 2 siklus yang masing-masing siklusnya terdiri dari tahap perencanaan, pelaksanaan tindakan, observasi, dan refleksi. Secara lebih rinci, tahapan-tahapan tersebut dapat dilihat dari bagan seperti di bawah ini:Berdasarkan skor standar maka kriteria untuk menentukan aktivitas guru dijabarkan pada tabel berikut : 


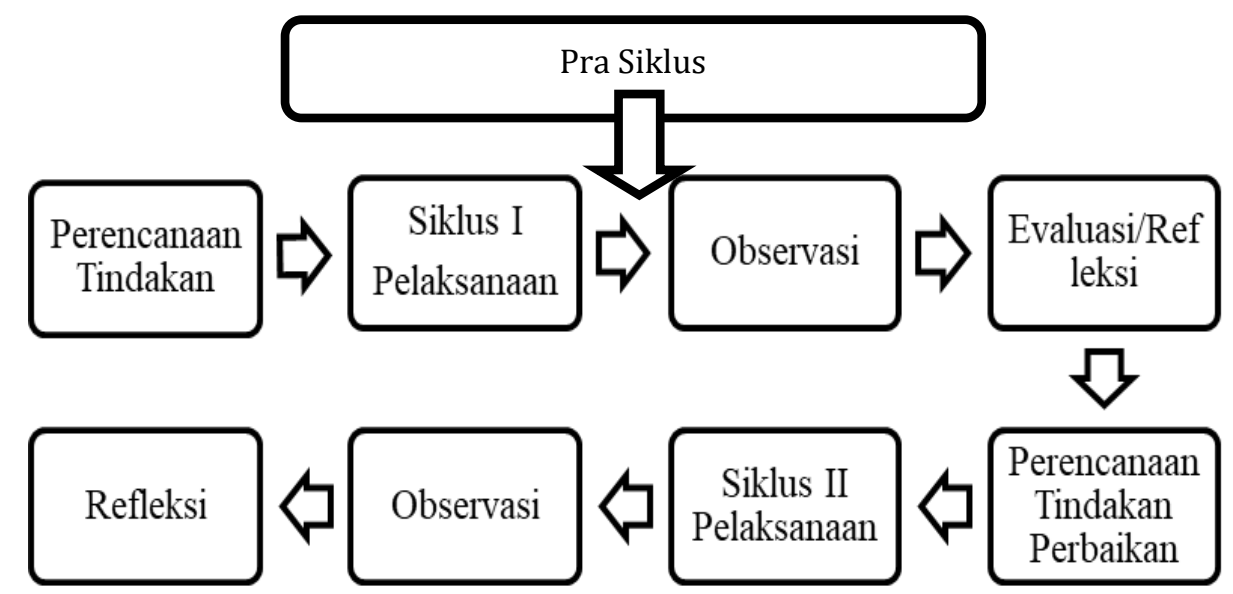

Pra Siklus (pre-cycle)

Gambar 1. Prosedur Siklus

Pada tahap ini akan dilakukan ijin terhadap sekolah dan merencanakan tentang materi apa yang akan diberikan kepada siswa serta dapat pula memberika latihan soal pada pra siklus guna mengetahui sejauh mana pemahaman siswa tentang materi tentang mata pelajaran yang bersangkutan. Lebih tepatnya bisa memulai mengenal dan memahami siswa dengan pendekatan langsung dan di dukung pula dengan wawancara dengan guru kelas.

Perencanaan Tindakan (planning)

Menurut (Saur, 2014) dalam tahapan ini akan disiapkan beberapa hal untuk mendukung penelitian seperti; 1) melakukan observasi, 2) menyusun RPP sesuai dengan kompetensi dasar dan indikator yang ingin di capai, 3) menyiapkan media pembelajaran yang dapat mendukung selama kegiatan, 4) menyiapkan instrument seperti lembar observasi dan latihan soal.

Pelaksanaan (acting)

Tahap pelaksanaan menurut (Agus, 2006) meliputi; 1) menyampaikan tujuan dan mempersiapkan peserta didik (Present Goals and Set), 2) menyajikan informasi (Present Information), 3) mengorganisir siswa dalam kelompok-kelompok belajar (Organize Students Onto Learning Teams), 4) membantu kerja kelompok belajar (Assist Team Work and Study), 5) evaluasi (Test on The Materials)

Observasi (observating)

Observasi dilakukan oleh observer dengan mengamati pada setiap pertemuan yang ada, ini berguna untuk perbaikan pada siklus selanjutnya. Dan melakukan feedback setelah pertemuan berakhir. Refleksi (reflecting)

Refleksi harus dilakukan pada setiap pertemuan, dengan melihat kelebihan serta kekurangan dan penemuan-penemuan yang ada pada siklus. Gunanya adalah untuk perbaikan pada siklus selanjutnya. Penelitian ini dilakukan di kelas IV SDN Salatiga 05, yang beralamatkan Jl. Kartini No. 53, Salatiga, Sidorejo, Kota Salatiga, Jawa Tengah 50711. Subjek penelitian ini adalah siswa kelas IV SDN Salatiga 05 dengan jumlah 20 siswa yang terdiri dari 9 siswa perempuan dan siswa 11 laki-laki. Nama guru kelas adalah Ibu Dewi Saraswati. Karakteristik siswa dari kelas ini adalah sebagian aktif sebagian masih kurang aktif. Beberapa sudah berpikiran logis, akan tetapi guru masih melakukan bimbingan kepada seluruh siswa kaitannya dengan pemecahan masalah dalam kehidupan sehari-hari.

Hasil dari hasil belajar siswa berupa data ketuntasan dalam bentuk interval dan persentase, sedangkang untuk instrument observasi akan diisi secara manual dengan memberikan catatan-catatan guna perbaikan untuk peneliti.

\section{Hasil dan Pembahasan}

Penelitian tindakan kelas ini dilakukan di kelas 4 semester 2 tahun pelajaran 2019/2020 Sekolah Dasar Negeri Salatiga 05, Kecamatan Sidorejo, Kota Salatiga pada mata pelajaran Matematika dengan materi Geometri menggunakan pendekatan kontekstual model learning community. Kelas 4 SDN Salatiga 05 memiliki jumlah murid 20 siswa yang terdiri dari 9 perempuan dan 11 laki-laki. Penelitian ini dilakukan dalam 2 siklus, dan disetiap siklusnya terdapat dua kali pertemuan. Dalam setiap pertemuan di siklus I dilakukan observasi terhadap guru dan siswa serta pemberian latihan soal guna melihat hambatan-hambatan yang terjadi selama siklus berlangsung serta hasil belajar siswa untuk melihat sejauh mana pemahaman siswa dan kemampuan berpikir kritis mereka dalam mengerjakan latihan soal pada 
mata pelajaran matematika materi geometri. Pencapaian yang diukur berdasarkan hasil dari lembar observasi dan latihan soal yang diberikan kepada siswa. Adapun standar pencapaian yang digunakan yaitu Kriteria Ketuntasan Minimal (KKM) sebanyak 75.

Dari hasil pembelajaran yang di dapatkan terjadi peningkatan yang signifikan dari mulai pra siklus sampai siklus II. Pada persentase hasil belajar di pra siklus siswa yang tuntas sebanyak $30 \%$ dan siswa yang tidak tuntas sebanyak 70\%. Kemudian mengalami peningkatan menjadi $60 \%$ untuk siswa tuntas pada siklus I dan puncaknya pada siklus II siswa mendapat kentuntasan $100 \%$ yang berarti seluruh siswa di kelas mendapatkan hasil di atas KKM. Berikut ini adalah hasil peningkatan dari pra siklus sampai siklus II sebagai berikut; 1) Pra siklus terdapat 6 memenuhi KKM dan naik menjadi 12 anak memenuhi KKM dengan peningkatan persentase sebanyak 60\% pada siklus I. 2) Dari 12 anak memenuhi KKM pada siklus I meningkat menjadi 20 anak memenuhi KKM yang berarti seluruh siswa di kelas tuntas dan terjadi peningkatan persentase sebanyak $40 \%$ pada siklus II.

Pada penelitian di siklus I dan siklus II peneliti menggunakan Learning Community method untuk menciptakan pembelajaran yang aktif dan mandiri terhadap siswa. Terlihat bahwa dari pra siklus hingga siklus I terjadi perubahan yang cukup signifikan, memang siswa belum sepenuhnya bisa beradaptasi dengan pembelajaran mandiri ini tetapi dari pertemuan satu sampai pertemuan terakhir siswa sudah mulai terbiasa dengan penerapan model ini. Siswa menjalankan tanggung jawabnya dengan baik. Adapun kelebihan dan kekurangan pada siklus I yang mengarah tentang pembiasaan siswa tentang bagaimana berkerja dalam kelompok, bertanggungjawab dengan tugasnya, serta ketrampilan siswa memecahkan persoalan dalam pembelajaran khususnya pada mata pelajaran matematika ini, yang mengharuskan siswanya berpikir kritis.

Untuk itu pada siklus II beberapa hal yang akan diperbaiki antara lain: 1) Meningkatkan keterlibatan siswa secara langsung dalam penjelasan materi, jadi guru bukan hanya menjelaskan tetapi siswa juga mendapat kesempatan mempraktikkan langsung di dalam kelas. 2) Siswa yang berkerja dalam kelompok harus memiliki data pribadi dari kegiatan atau pembahasan tentang materi yang mereka pelajari. 3) Memperluas pengetahuan siswa lewat kegiatan yang beragam. 4) Melakukan review guna mengingatkan siswa kembali tentang materi yang sudah mereka pelajari pada siklus I. 5) Melakukan latihan soal lagi dengan beberapa revisi dan penyempurnaan dari hasil validitas. Dari perbaikan ini terjadi peningkatan yang signifikan terhadap siswa baik dalam kegiatan maupun hasil kerja mereka berupa diskusi dan tes serta meningkatnya ketrampilan berpikir kritis siswa dalam kegiatan kelompok dan pemecahan soal tes. Teori belajar menurut (Johnson, 2006) pembelajaran mandiri melibatkan pengaitan studi akademik dengan kehidupan sehari-hari dalam cara yang bermakna untuk mencapai tujuan yang berarti. Maka dari itu pendekatan kontekstual (pembelajaran mandiri) dengan model learning community untuk melibatkan seluruh siswa secara aktif melalui pemberian peran dalam kelompok meningkatkan hasil belajar dan ketrampilan berpikir kritis siswa.

\section{Simpulan Dan Saran}

Pembelajaran yang menggunakan metode ceramah dan tanya jawab saja tidak memberikan kesempatan siswa untuk memaksimalkan kemampuan yang mereka miliki. Setiap siswa berhak memiliki kesempatan untuk melihat, menemukan, menyimpulkan, dan membagikan hasil kerjanya dengan sistem diskusi. Terlebih untuk pembelajaran matematika materi geometri, kegiatan praktek dan penggunaan media pembelajaran sangat membantu dalam memahami konsep dari materi tersebut. Sebelum penelitian hasil dari tes siswa cukup rendah karena hanya ada 6 anak yang memenuhi KKM. Pada siklus I penggunaan media serta pembagian tugas dalam kelompok membuat siswa tertarik untuk lebih mendalami tentang materi geometri, dan mengalami peningkatan ketuntasan KKM yaitu terdapat 12 siswa tuntas.

Untuk lebih meningkatkan dan mendukung pembelajaran yang berhasil peneliti menggunakan Learning Community sebagai model pembelajaran yang di gunakan, di dalamnya terdapat pembagian peran untuk setiap anggota kelompok seperti leader, note taker, summarize, presentor. Dari pembagian peran ini siswa memiliki tanggungjawab masing-masing dan juga memiliki kesempatan untuk membagikan hasil diskusi dalam kelompok dengan kelompok lain menggunakan sistem berdiskusi secara berpasangan. Terbukti penerapan kontekstual model Learning Community ini meningkatkan hasil belajar dan ketrampilan berpikir siswa dalam kegiatan kelompok dan tes individu dan mencapai KKM untuk seluruh siswa di kelas IV SDN Salatiga 05 tahun pelajaran 2019/2020

Saran dari penelitian ini diharapkan akan berguna untuk:

\section{a. Untuk Sekolah}

Berdasarkan hasil yang diperoleh selama penelitian, dengan melihat penemuan serta hambatan yang terjadi selama siklus dan perbaikan pada setiap siklusnya. Diharapkan sekolah memiliki wadah 
dan sarana terhadap para siswa untuk mengembangkan ketrampilan siswa kaitannya dengan pembelajaran matematika, siswa memiliki kesempatan mendapat sarana dan media pembelajaran yang akan mendukung dan menguatkan siswa tentang konsep yang mereka pelajari.

b. Untuk Guru

Penelitian ini dapat dijadikan referensi untuk guru kaitannya dengan meningkatkan kreatifitas guru dalam memberikan kegiatan untuk siswa. Pembelajaran matematika bukan hanya tentang rumus apa yang dipakai, tetapi lebih kepada sejauh mana siswa memahami konsep yang ada, dan diharapkan siswa akan selalu mendapat hasil yang memenuhi KKM

c. Untuk Peneliti

Penelitian ini dapat dijadikan referensi untuk mengajar di kelas pada masa yang akan datang, dan kegiatan yang ada bisa meningkatkan kreatifitas peneliti untuk modifikasi pembelajaran yang dapat memenuhi kebutuhan siswa pula.

\section{Daftar Rujukan}

A. Matalang, U. K. (2009). Meningkatkan Hasil Belajar Siswa Kelas III SDN Pembina Liang Pada Pokok Bahasa Luas Segitiga Melalui Pendekatan Kontekstual. Jurnal Kreatif Tadulako .

Agus, S. (2006). Cooperative Learning, Teori \& Aplikasi PAIKEM. Surabaya: Pustaka Pelajar.

Alwasih, A. C. (2006). Contextual Teaching and Learning. Bandung: Mizan Media Utama.

Amir, M. F. (2015). Pengaruh Pembelajaran Masalah Matematika Siswa Sekolah Dasar. Porsiding Seminar Nasional Pendidikan, 34-42.

Andari, T. (2016). Efektifitas Pembelajaran Matematika Menggunakan Pendekatan Kontekstual Terhadap Prestasi Belajar Matematika Ditinjau dari Kemampuan Siswa KelasV SD- Kecamatan Bangunrejo Kabupaten Lampung Tengah. Jurnal Ilmiah Pendidikan Matematika .

Ardiyanto, D. S. (2013). Pengaruh Pendekatan Kontekst. Prosiding Universitas Yogyakata , 174-184.

Benjamin, S. B. (2005). Taxonomy of Education Objectives. New York: Longman.

Hamzah, A., \& Muhlisrarini. (2014). Perencanaan dan Strategi Pembelajaran Matematika. Jakarta: Raja Grafindo Persada.

Hasnawati. (2006). Pendekatan Contextual Teaching Learning Hubungannya dengan Evaluasi Pembelajaran. Jurnal Ekonomi dan Pendidikan , 53-62.

Johnson, E. B. (2006). Contextual Teaching and Learning. Bandung: Mizam Learning Center.

Karim, A. (2011). Penerapan Metode Penemuan Terbimbing dalam Pembelajaran Matematika untuk Meningkatkan Pemahaman Konsep dan Kemampuan Berpikir Kritis Siswa Sekolah Dasar. Jurnal Pendidikan , 21-32.

Masita, M. (2012). Peningkatan Aktivitas Siswa pada Pembelajaran Matematika Melalui Pendekatan Kontekstual (Contekstual Teaching and Learning). Jurnal Pendidikan Matematika .

Mills, G. E. (2000). Action Research: a guide for teacher researcher. . London: Printice-Hall International (UK) Limited.

Mulyasa. (2008). Menjadi Guru Profesional Menciptakan Pembelajaran Kreatif dan Menyenangkan. Bandung: PT. Remaja Rosdakarya.

Muslich, M. (2011). Pembelajaran Berbasis Kompetensi dan Kontekstual. Jakarta: Bumi Aksara. 
Mustaji. (2012). Developing Critical Thinkers (Brookfield). San Fransisco: Jossey Bass Publiser.

Nasional, D. P. (2003). Pendekatan Kontekstual (Contextual Teaching and Learning/CTL). Jakarta: Depdiknas, Direktorat Jendral Pendidikan Dasar Dan Menengah Dan Lanjut Pertama.

Noor, J. (2010). Metodologi Penelitian: Skripsi, Tesis,Disertasi dan Karya Ilmiah. Jakarta: Prenadamedia Group.

Nurhadi. (2003). Pembelajaran Kontekstual dan Penerapannya dalam KBK. Malang: Universitas Negeri Malang.

Payung, Z. (2015). Penerapan Contextual Teaching and Learning Untuk Meningkatkan Hasil Belajar Matematika Siswa Kelas IV SDN 189 Malimbong Kabupaten Tana Toraja. AgroSainT , 120-124.

Puspita, Dewi. (2017). Pengaruh Keterampilan Berpikir kritis dan Berpikir Kreatif Terhadap Hasil Belajar Mata Pelajaran Ekonomi Kelas X IPS 1 Di Man Mojosari. Volume 5 No 1 Edisi Yudisium 2017.

Rahman, A. (2012). Implementasi CTL dalam Meningkatkan Pemahaman Konsep Matematika Siswa. Jurnal Pendidikan Matematika UNP.

Sanderayanti, D. (2015). Pengaruh Motivasi Belajar dan Kemampuan Berpikir Kritis terhadap Hasil Belajar Matematika Siswa di SDN Kota Depok. Jurnal Pendidikan Dasar, 222-231.

Saur, T. (2014). Penelitian Tindakan Kelas. Jakarta: Erlangga.

Sudjana, N. (2009). Penilaian Hasil Proses Belajar Mengajar. Bandung: Remaja Rosdakarya.

Sulianto, J. (2008). Pendekatan Kontekstual Dalam Pembelajaran Matematika untuk Meningkatkan Berpikir Kritis pada Siswa Sekolah Dasar. Jurnal Pendidikan Matematika 4 , 14-25.

Wardani, N. S. (2012). Asesmen Pembelajaran SD. Salatiga: Widya Sari Press Salatiga. 